\title{
Catalytically active guanylyl cyclase-B requires glycosylation and mutations that inhibit this process cause dwarfism
}

\author{
Deborah M Dickey, Aaron B Edmond, Thomas Chaffee, Lincoln R Potter \\ From 7th International Conference on cGMP Generators, Effectors and Therapeutic Implications \\ Trier, Germany. 19-21 June 2015
}

\section{Background}

C-type natriuretic peptide (CNP) is a paracrine factor that stimulates long bone growth, axonal path finding and inhibits meiosis in the oocyte [1]. The biologic signaling receptor for CNP is guanylyl cyclase (GC)-B, also known at NPRB or NPR2 [2].

GC-B is a homo-oligomer, possibly a dimer, containing a glycosylated extracellular ligand-binding domain, a single membrane-spanning region, and intracellular kinase homology domain (KHD), dimerization domain and C-terminal GC catalytic domain. Phosphorylation of the region leading into and at the beginning of the kinase homology domain is required for CNP activation of GC-B and dephosphorylation inactivates the enzyme [3].

Homozygous inactivating mutations in GC-B result in Acromesomelic Dysplasia, Type Maroteaux (AMDM) dwarfism [4-6], and heterozygous inactivating mutations in GC-B cause non-pathological reductions in stature [7]. Conversely, genetic mutations that increase GC-B activity result in skeletal overgrowth [8-10].

More than fifteen inactivating missense mutations in GC-B have been identified in humans. These mutations are randomly distributed from the $\mathrm{N}$-terminus (P32) to the C-terminus (G959A) of the enzyme, consistent with two potential mechanisms. The first involves multiple processes like disruption of CNP or GTP binding to the extracellular or catalytic domains, respectively. The second more general mechanism involves conformational changes in secondary, tertiary or quaternary structure that preclude catalytic domain formation or activation.

Previous investigators reported that 11 out of 12 [1], 2 out of 3 [2] or 1 out of 2 [3] missense mutations inhibited

\footnotetext{
* Correspondence: potter@umn.edu

Department of Biochemistry, Molecular Biology and Biophysics, University of Minnesota, Minneapolis, MN, USA
}

\section{Results}

$A M D M$ mutants are incompletely processed- Post-or co-translational processing of the four intracellular AMDM causing mutants (L658F, Y708C, R776W and G959A) was compared against WT-GC-B and GC-B-7A, a mutant containing alanine substitutions for all known phosphorylation sites [3], in reduced SDS gels containing immunoprecipitated receptors isolated from transiently transfected $293 \mathrm{~T}$ cells. Coomassie staining (Fig. 1, upper panel) of WT-GC-B revealed a slower migrating, diffuse species (top band) that is maximally glycosylated and phosphorylated and a faster migrating species (bottom band) that is incompletely glycosylated and is not sphorylated [3-14]. The upper band was also present samples from GC-B-7A indicating that changes in sphorylation does not account for the difference in

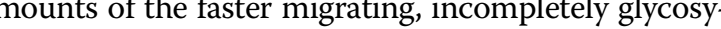
GC species. ProQ Diamond staining, a dye that binds gel indicated thate-dependent manner [5], of the same WT receptor was phosphorylated (Fig. 1, lower panel).

The AMDM GC-B Mutants Are On the Cell Surface and Bind CNP- 125I-CNP binding assays were performed 


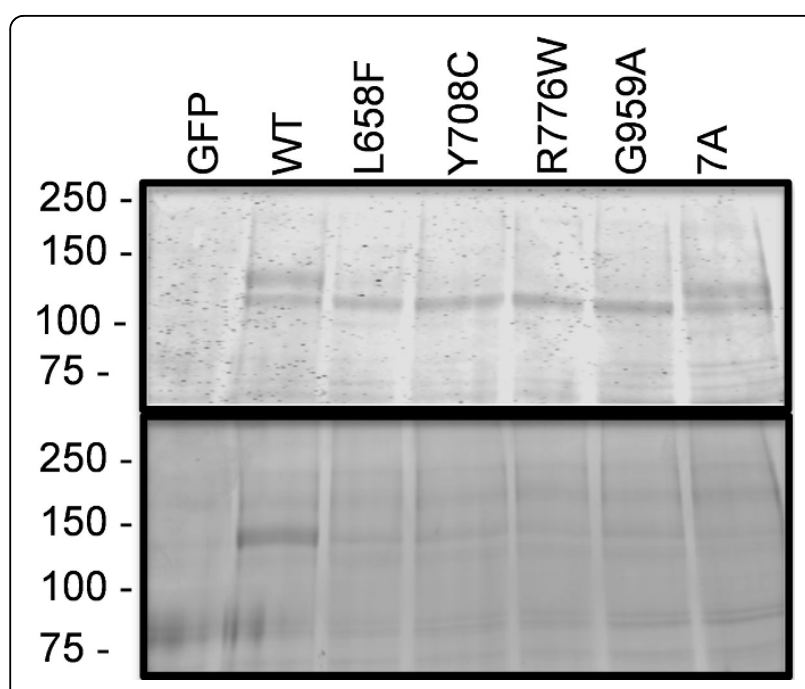

Figure 1 AMDM mutants are not processed to the fully glycosylated and phosphorylated form of GC-B. WT and the indicated missense versions of GC-B were isolated from transiently transfected 293T cells by sequential immunoprecipitatin/SDS-PAGE purification. The resulting gel was incubated with ProQ Diamond dye to determine GC-B phosphate levels (lower panel). The same gel was then washing and stained with Coomassie to determine the amount of GC-B protein present (upper panel). MW in KiloDaltons is shown for protein standards on left. Abbreviations are: GFP, green fluroscent protein; 7A, GC-B containing alanine substitutions for all seven known phosphorylation sites.

on live 293T cells transfected with the individual AMDM mutants, WT-GC-B as a positive control, and GFP as a negative control (Fig. 2, upper panel). Low radiation levels in GFP transfected cells and in GC-B expressing cells incubated with excess non-radioactive CNP (nonspecific binding), confirmed that the binding was specific for GCB. All four mutants specifically bound 125I-CNP, consistent with GC-B being on the cell surface. Total 125I-CNP binding to each mutant was variable and less than that observed for the WT receptor, which is expected since the mutants lack the upper completely processed species only seen in WT-GC-B (Fig. 1, upper panel). Competition binding assays indicated that the affinity of each mutant for CNP was similar to that of the WT-GC-B (Fig. 2, lower panel). These data indicate that all four mutants are on the cell surface and that glycosylation of GC-B is neither required to bind $\mathrm{CNP}$ nor required for $\mathrm{GC}-\mathrm{B}$ to adopt a conformation capable of binding CNP.

AMDM mutants have dramatically reduced GC activityThe ability of the GC-B mutants to form active catalytic domains that can be stimulated by CNP or non-ionic detergent and manganese was tested in membranes from transfected 293 cells (Fig. 3). GC activity was measured under basal $(\mathrm{Mg} 2+\mathrm{GTP}$ and ATP), CNP-stimulated (Mg2+GTP, ATP, CNP) and artificial (Mn2+GTP and Triton $\mathrm{X}-100)$ conditions. The latter activates the enzyme

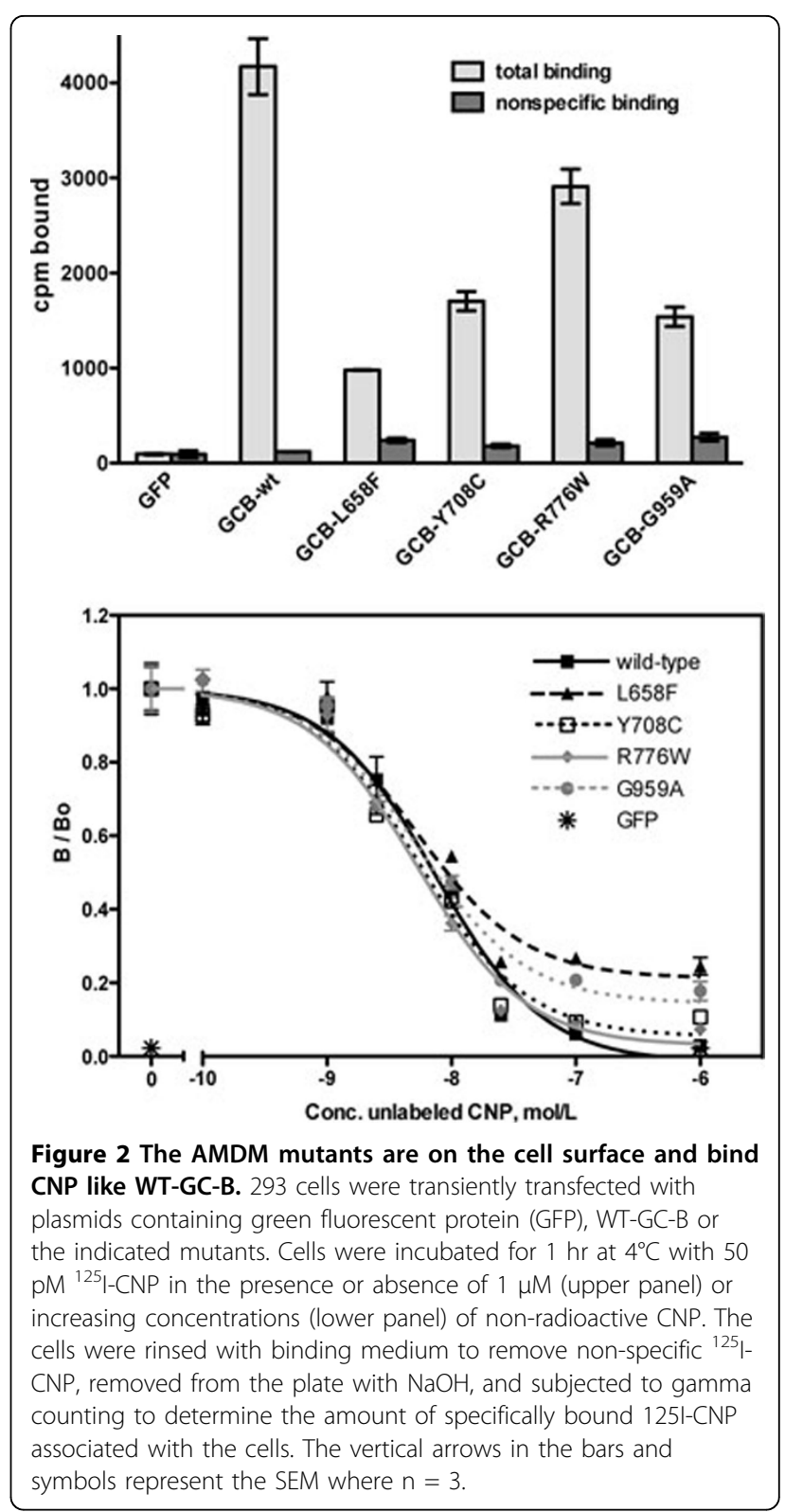

independently of natriuretic peptide or phosphorylation and is an excellent indicator of total catalytic domain formation [3]. No significant differences were observed under basal condition but GC activities of the mutant enzymes measured under CNP- and detergent conditions was less than $20 \%$ of the activity observed for WT-GC-B. Since the AMDM mutations inhibit activity in the presence of detergent and CNP, it suggests that catalytic domain formation is inhibited as opposed to inhibiting CNP-dependent activation of a preformed catalytic domain.

\section{Conclusion}

We conclude that glycosylation of GC-B is required for active catalytic domain formation and that the majority 


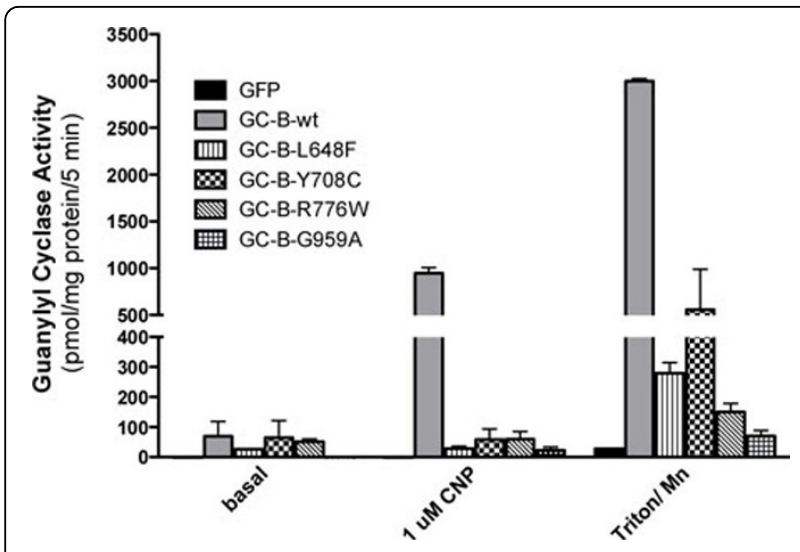

Figure 3 The AMDM mutants have markedly reduced guanylyl cyclase activity. 293 cells were transiently transfected with plasmids containing green fluorescent protein (GFP), WT-GC-B or the indicated mutants of GC-B. Crude membranes were prepared from the transfected cells and assayed for guanylyl cyclase activity under basal, CNP-stimulated or Triton X-100 and manganesestimulated conditions. The vertical arrows in the bars and symbols represent the SEM where $n=3$.

of GC-B mutations that reduce stature inactivate the enzyme by decreasing receptor glycosylation not by inhibiting trafficking to the plasma membrane.

\section{Acknowledgements}

This work was supported by NIH grants R01GM098309 to L.R.P and T32AR050938 to A.B.E.

Published: 2 September 2015

\section{References}

1. Potter LR: Regulation and therapeutic targeting of peptide-activated receptor guanylyl cyclases. Pharmacol Ther 2011, 130(1):71-82.

2. Potter LR: Guanylyl cyclase structure, function and regulation. Cell Signal 2011, 23(12):1921-1926.

3. Potter $L R$, Hunter $T$ : Identification and characterization of the major phosphorylation sites of the B-type natriuretic peptide receptor. $J$ Biol Chem 1998, 273(25):15533-15539.

4. Bartels CF, Bukulmez H, Padayatti P, Rhee DK, van Ravenswaaij-Arts C, Pauli RM, et al: Mutations in the transmembrane natriuretic peptide receptor NPR-B impair skeletal growth and cause acromesomelic dysplasia, type Maroteaux. Am J Hum Genet 2004, 75(1):27-34.

5. Hachiya R, Ohashi Y, Kamei Y, Suganami T, Mochizuki H, Mitsui N, et al: Intact kinase homology domain of natriuretic peptide receptor- $B$ is essential for skeletal development. J Clin Endocrinol Metab 2007, 92(10):4009-4014.

6. Khan S, Hussain Ali R, Abbasi S, Nawaz M, Muhammad N, Ahmad W: Novel mutations in natriuretic peptide receptor-2 gene underlie acromesomelic dysplasia, type maroteaux. BMC Med Genet 2012, 13:44.

7. Olney RC, Bukulmez H, Bartels CF, Prickett TC, Espiner EA, Potter LR, Warman ML: Heterozygous mutations in natriuretic peptide receptor-B (NPR2) are associated with short stature. J Clin Endocrinol Metab 2006, 91(4):1229-1232

8. Hannema SE, van Duyvenvoorde HA, Premsler T, Yang RB, Mueller TD, Gassner B, et al: An activating mutation in the kinase homology domain of the natriuretic peptide receptor- 2 causes extremely tall stature without skeletal deformities. J Clin Endocrinol Metab 2013, 98(12):E1988-E1998.

9. Miura K, Kim OH, Lee HR, Namba N, Michigami T, Yoo WJ, et al: Overgrowth syndrome associated with a gain-of-function mutation of the natriuretic peptide receptor 2 (NPR2) gene. Am J Med Genet A 2014, 164A(1):156-163.

10. Miura K, Namba N, Fujiwara M, Ohata Y, Ishida H, Kitaoka T, et al: An Overgrowth Disorder Associated with Excessive Production of cGMP Due to a Gain-of-Function Mutation of the Natriuretic Peptide Receptor 2 Gene. PLoS One 2012, 7(8):e42180.

11. Hume AN, Buttgereit J, Al-Awadhi AM, Al-Suwaidi SS, John A, Bader M, et al: Defective cellular trafficking of missense NPR-B mutants is the major mechanism underlying acromesomelic dysplasia-type Maroteaux. Hum Mol Genet 2009, 18(2):267-277.

12. Vasques GA, Amano N, Docko AJ, Funari MF, Quedas EP, Nishi MY, et al: Heterozygous mutations in natriuretic peptide receptor-B (NPR2) gene as a cause of short stature in patients initially classified as idiopathic short stature. J Clin Endocrinol Metab 2013, 98(10):E1636-E1644.

13. Amano N, Mukai T, Ito Y, Narumi S, Tanaka T, Yokoya S, et al: Identification and functional characterization of two novel NPR2 mutations in Japanese patients with short stature. J Clin Endocrinol Metab 2014, 99(4): E713-E718.

14. Potter LR: Phosphorylation-dependent regulation of the guanylyl cyclaselinked natriuretic peptide receptor $B$ : dephosphorylation is a mechanism of desensitization. Biochemistry 1998, 37(8):2422-2429.

15. Bryan PM, Smirnov D, Smolenski A, Feil S, Feil R, Hofmann F, et al: A sensitive method for determining the phosphorylation status of natriuretic peptide receptors: CGK-lalpha does not regulate NPR-A. Biochemistry 2006, 45(4):1295-1303.

doi:10.1186/2050-6511-16-S1-A44

Cite this article as: Dickey et al: Catalytically active guanylyl cyclase-B requires glycosylation and mutations that inhibit this process cause dwarfism. BMC Pharmacology and Toxicology 2015 16(Suppl 1):A44.

\section{Submit your next manuscript to BioMed Central and take full advantage of:}

- Convenient online submission

- Thorough peer review

- No space constraints or color figure charges

- Immediate publication on acceptance

- Inclusion in PubMed, CAS, Scopus and Google Scholar

- Research which is freely available for redistribution 